\title{
INNOVATIVE APPLICATION OF CONTEMPORARY MANAGEMENT METHODS IN A KNOWLEDGE-BASED ECONOMY - INTERDISCIPLINARITY IN SCIENCE
}

\author{
Joanna EJDYS ${ }^{1}$, Leonas USTINOVIČIUS ${ }^{2}$, Jelena STANKEVIČIENË ${ }^{3}$ \\ 1,2 Bialystok Technical University, Faculty of Management, \\ Tarasiuka 2 Street, 16-001 Kleosin, Poland \\ ${ }^{2}$ Vilnius Gediminas Technical University, Faculty of Civil Engineering, \\ Sauletekio al. 11, LT-10223 Vilnius, Lithuania \\ ${ }^{3}$ Vilnius Gediminas Technical University, Faculty of Business Management, \\ Sauletekio al. 11, LT-10223 Vilnius, Lithuania \\ E-mails: ${ }^{j}$ j.ejdys@pb.edu.pl; ${ }^{2}$ leonas.ustinovicius@vgtu.lt; \\ 3jelena.stankeviciene@vgtu.lt (correspondingauthor)
}

Received 17 October; accepted 07 November 2014

\begin{abstract}
Interdisciplinarity, which is a part of the research paradigm in all fields of science, constitutes a real challenge in research. It manifests itself particularly in the diversity of the undertaken research topics, in the variety of the adopted research approaches (theoretical, methodological, normative, empirical-descriptive), and in the flexibility and the ability to see both the scientific problems as well as the economic and social needs. The ability to cross the boundaries between the fields of technical and social sciences, to identify problems and to seek solutions at the frontiers of scientific disciplines, the eagerness to work in research teams diverse in terms of competence, age and skills, creating conditions for both the personal development and that of individual team members, breaking the stereotypical ways of thinking in the process of solving problems and anticipating future events are all features of an academic culture nurtured by Professor Joanicjusz Nazarko. The paper highlights the research of Professor Joanicjusz Nazarko, presents a review of his extensive scientific work and lists some of his publications.
\end{abstract}

Keywords: Data Envelopment Analysis (DEA), benchmarking, foresight, regional business information foresight, electric energy market, productivity, scenario method.

JEL Classification: O3, I2, C4.

\section{Introduction}

"Science and everyday life cannot and should not be separated"

Rosalind Franklin (1920-1958)

What is clear is that science will need new kinds of scientists, many of whom will need to be first-rate in more than one field of science as scientific research increasingly needs to occur across traditional scientific boundaries (Winiwarter 2014). The challenge for 
science as a whole is the interdisciplinarity, which is part of the paradigm of research in all fields. The most commonly accepted definitions of interdisciplinarity come from the OECD (1998), in which multi-disciplinarity, interdisciplinarity, and transdisciplinarity are used in reference to the increasing of levels of interaction among disciplines. Thus, in multidisciplinary research, the subject under study is approached from different angles, using different disciplinary perspectives and integration which is not accomplished. Interdisciplinary research leads to the creation of a theoretical, conceptual, and methodological identity, so more coherent and integrated results are obtained. Finally, transdisciplinarity goes one step further and it refers to a process in which convergence among disciplines is observed, and it is accompanied by a mutual integration of disciplinary epistemologies (Morillo et al. 2003). The importance of interdisciplinary research is widely recognized, since cross-disciplinary research is associated with creativity, progress, and innovation, and many of the intellectual "breakthroughs" of modern times were obtained by crossing disciplinary boundaries.

Interdisciplinarity means crossing the boundaries between disciplines, recognizing problems and ways of solving them, in a manner often unconventional, different from the monophonic approach. The tools enabling solving problems from the borderline of disciplines include: methods of analysis of the productivity of organizations (Data Envelopment Analysis, benchmarking), and the foresight research methodology.

Data Envelopment Analysis (DEA) is a methodology originally used in the area of operational research, where the interest is to compare different and independent units (firms, departments, etc.) in relation to their productive efficiency. Existing applications of DEA include particularly analysing the productive performance of health care services (Deidda et al. 2014); assessment of transport systems (Fancello et al. 2014; Zhou et al. 2014), measuring environmental performance (Nabavi-Pelesaraei et al. 2014; Yang et al. 2014), performance of financial systems (Ebrahimnejad et al. 2014; Gunawan, Shieh 2014; Perek 2014) and indicate significant potential for use of the method in other areas. The Data Envelopment Analysis method occupies an important place in the comparative efficiency studies in the public sector worldwide. Examples of DEA application in the area of higher education from around the globe are described in works by Leitner et al.(2007), Figueiredo de Franca et al. (2010), Bougnol and Dula (2006) and also by Nazarko (Nazarko 2010; Nazarko, Saparauskas 2014; Nazarko et al. 2008c). Benchmarking is also widely used in the public sector represented by the higher education (Agasisti, Bonomi 2014; Kuźmicz 2013; Nazarko et al. 2009b; Skourdoumbis 2014).

While the two mentioned above tools allow for static evaluation of the effectiveness of units, without taking into account the time factor, and their comparison to the best, the third tool, "foresight", takes into account the time factor and allows for a systematic anticipation of the future states of reality. In simple translation, the English word foresight stands for anticipation, prediction. This translation, however, narrows the meaning of the term. Due to the lack of a commonly accepted equivalent of the word "foresight" in Polish and in many other languages, the English term is used in the literature. The closest possible meaning of the term "foresight" may be its translation as "active building of future's image". According to Keenan and Miles, foresight is a systematic participation- 
based process of building medium- and long-term vision aimed at present decisions, and putting forth common actions (Keenan, Miles 2001). The interdisciplinarity of foresight research is indicated by its current areas of application. These include: regional development (Docksai 2012); trade policy, including the energy policy (Doukaset al. 2014; Hansen 2008), innovation policy (Hansen 2008; Magruk 2012; Wiley 2007); public policy (Coelho et al. 2012; Habegger 2010; Nehme et al. 2012).

Prof. J. Nazarko, in more than 30 years of his professional work, has significantly contributed to the development of the above-mentioned tools from the methodological and application perspectives. He pointed to the current weaknesses of these tools, to the methods of their improvement and to the areas of new applications.

\section{Scientific interdisciplinarity}

The scientific path of Prof. J. Nazarko was not a typical one. His interests and scientific achievements evolved over time from the field of technical sciences to the field of economic sciences. In the period before obtaining a postdoctoral degree in technical sciences, the mainstream of his research was related to the control and management of the operation of power systems under the conditions of uncertainty. Even then, however, a part of his works combined the issues from the areas of technical and economic sciences, which was reflected in several important publications. In the period before obtaining the title of professor of technical sciences, the acquis of Joanicjusz Nazarko contained a number of achievements in the field of economic sciences:

- development of the theory of information systems in the field of power management;

- development of methods for managing the demand for electric energy;

- development of research on the model of the local electric energy market;

- development and adaptation of modern research methods (methods of artificial intelligence, theory of probability and statistics) to the issues of power management and control.

The tangible effect of the research conducted by J. Nazarko at that time comprised several major publications of interdisciplinary character in journals of global (Broadwater et al. 1997; Sargent et al. 1994; Nazarko, Zalewski 1999; Nazarko et al.1998) and national reach (Nazarko, Jurczuk 1996). The nature and specificity of the field of technical sciences, being the main concern of the scientific achievements of Prof. J. Nazarko, require the interdisciplinary approach, both in purely theoretical-cognitive, as well as application terms. This interdisciplinarity of the research of J. Nazarko became more pronounced after obtaining the postdoctoral degree in technical sciences.

After obtaining the academic title of professor of technical sciences in 1998, J. Nazarko reoriented his research interests in the direction of management sciences even more clearly. Working at the Faculty of Management at the Bialystok University of Technology, Prof. J. Nazarko gained significant scientific achievements in the field of economic sciences, focused mainly on management science, creating a personal research program, which can be defined as a custom application of selected modern management methods 
in knowledge based society. Within this program, special attention should be paid to the Professor's contribution in the expansion of knowledge concerning:

- the theory and methods of analysis of the productivity of organizations,

- the concept of benchmarking in the public sector,

- the theory and methodology of foresight research.

In the opinion of Professor Marian Gorynia, all interests and achievements of Prof. J. Nazarko in the area of economic sciences create a unique set of research results. This acquis has been built in an incremental manner, taking into account the needs of the economy and the scientific advances.

The results of the research carried out individually or in research teams were announced by Prof. J. Nazarko systematically in the form of articles and papers presented at numerous conferences - abroad and domestic.

\section{Data Envelopment Analysis in the research of productivity of the public sector}

An important area of the scientific inquiry of Prof. J. Nazarko in the field of economic sciences concerns the productivity analysis of organizations. He is one of the national precursors in the application of the method of Data Envelopment Analysis in the research concerning the productivity of the public sector, particularly of the higher education institutions. The creative contribution of Prof. J. Nazarko to the development of the methodology and applications of DEA in the comparative analysis of the productivity of organizations is visible primarily in proposing the procedures of the statistical verification and the selection of data for the models, the study of stability and sensitivity of DEA models to interference in the data and conducting comparative studies of the productivity of Polish technical universities. The following works should be considered as an innovative development of the concept of productivity in the public sector:

- indication of the possibilities of application of the DEA method in the study of productivity of the public sector (Nazarko, Saparauskas 2014; Nazarko et al. 2008c, 2012a; Nazarko 2010; Nazarko, Ustinovičius 2012);

- proposing a statistical procedure of verification and selection of data for the DEA models (Nazarko, Saparauskas 2014; Nazarko, Urban 2007);

- performance of comparative studies of productisvity of the Polish technical universities (Nazarko, Saparauskas 2014; Nazarko et al. 2008c, 2012a);

- study of the stability and sensitivity of DEA models to the interference in the data (Nazarko, Urban 2007).

\section{The development of the theory of benchmarking in the public sector}

Prof. J. Nazarko was a pioneer of the idea of benchmarking in the higher education sector in Poland. The value of the scientific achievements of Prof. J. Nazarko in the development of the concept of benchmarking consists primarily of:

- indicating the importance of benchmarking in improving the quality of scientific research and higher education (Nazarko et al. 2007a, 2007b, 2008a, 2008b, 2009c; Vught et al. 2008); 
- extension of the concept of process benchmarking in relation to higher education as a tool for increasing the productivity of universities (Nazarko et al. 2008b, 2009b; Vught et al. 2008);

- developing the concept of Kelly's benchmarking spiral in relation to the process of higher education institutions benchmarking (Nazarko et al. 2008b, 2009a, 2009b, 2009c);

- defining objectives, types and phases of benchmarking in relation to higher education (Nazarko et al. 2007a, 2008b, 2009b).

J. Nazarko actively participated in international and national benchmarking initiatives. He took part in two international projects as an expert. They concerned the European benchmarking initiative in higher education, carried out by the European Centre for Strategic Management of Universities (ESMU, Brussels) and the Career Development in Higher Education Management project implemented by the Centrum für Hochschulentwicklung (CHE, Germany). In the years 2006-2011 Prof. J. Nazarko was a member of the Steering Committee of the "Benchmarking in Higher Education" project carried out at the initiative of the Polish Rectors Foundation, and in 2010 he participated in the development of a project entitled "Higher Education Development Strategy 2010-2020".

\section{Development of the theory and methodology of foresight research}

Foresight research - with its own terminology and research instrumentarium - is constantly gaining in importance. The proof of this is the growing catalogue of foresight initiatives that, worldwide, consists of more than two thousand projects, and in Poland already contains about fifty items, as well as the increasing number of publications on the topic of foresight research in the leading journals in the field of management. At the same time, this method demonstrates a number of methodological gaps and is under constant development (Nazarko et al. 2013d; Nazarko, Kononiuk 2013). Foresight can be regarded as a good example of interdisciplinarity in science.

Since 2006, the cognitive attention of Prof. J. Nazarko has focused on research in the field of foresight and technology management, with particular emphasis on technology foresight. Foresight studies have already been distinguished as a distinct specialty within the management sciences. The subject of the conducted research builds alternative visions of the future of science, technology, environment, economy and society. The key role of foresight is to stimulate and support various organizations in formulating their policies and strategies.

Most scientific achievements by Prof. J. Nazarko came into being in the framework of research projects and research grants. He was a member of the Steering Committee in the National Foresight Programme "POLAND 2020"at the Ministry of Science and Higher Education. On his initiative a Support Group to the Steering Committee has been appointed, composed of young researchers (Kononiuk et al. 2007; Jakuszewicz et al. 2006). This was the basis for the formation of a research team in the field of foresight research under his direction. 
In 2009, together with the established research team, he obtained funds (under the Innovative Economy Operational Programme) for the research project entitled "NT FOR Podlaskie 2020. Regional strategy for the development of nanotechnology" that dealt with the issues of technological foresight.

The aim of the research carried out in the project was to determine the strategic directions of development of the region of Podlasie, based on the paradigm of abrupt increase in productivity resulting from the implementation of innovative manufacturing processes utilizing developments in nanotechnology. The project resulted in a lot of original research findings, bringing a significant contribution to the development of management sciences. The following results should be emphasized:

- projection of the nanotechnology development strategy in the region of Podlasie (Nazarko 2011a; Nazarko et al. 2013a, 2013b, 2013e);

- creation of nanotechnology development routes in the Podlaskie province (Nazarko et al. 2013b);

- development of a methodology of mapping key and priority technologies (Nazarko et al. 2011a, 2013b);

- selection of key nanotechnologies for the economy of the Podlaskie province (Nazarko et al. 2013d);

- indication of the priority directions of research in the field of nanotechnology for the development of the Podlaskie province (Nazarko et al. 2013c);

- characterization of megatrends and trends affecting the development of nanotechnology in the Podlaskie province (Nazarko et al. 2013a, 2013b);

- formulation of scenarios of the development of nanotechnology in the Podlaskie province (Nazarko et al. 2013a);

- identification of SWOT factors of and the assessment of their significance in the years 2010 and 2020 (Nazarko et al. 2010);

- examination of the substantial scope of factors identified within the framework of STEEPVL analysis of the development of nanotechnology (Nazarko et al. 2010);

- statistical analysis of the results of the STEEPVL analysis of nanotechnology development in the region (Nazarko et al. 2011b).

In 2010, the Ministry of Science and Higher Education commissioned the team under the direction of J. Nazarko to perform the evaluation of foresight projects implemented in Poland. The monograph, created as a result of the research, edited by the initiator entitled Evaluation study of foresight projects implemented in Poland is currently the most complete compendium of knowledge about Polish foresight initiatives (Nazarko et al. 2012b). The monograph, published as a result of a research project sponsored by the National Science Centre (Kononiuk, Nazarko 2014) presented an original methodology of designing scenarios in foresight studies (Nazarko, Kononiuk 2013).

In the years 2011-2013 J. Nazarko, conducted a project on Foresight studies in the area of innovation of Mazovia companies comissioned by the Association of Employers of Warsaw and Mazovia. It is worth noting that this was the first foresight study in Poland carried out by an NGO. The primary objective of this project was to develop a model of regional foresight studies carried out for the needs of non-scientific organizations, 
which would be the basis for conducting similar studies in the future. Essential informative function of foresight studies, which consists of providing anticipatory knowledge of the possible options for the future, was exhibited there. The scientific results of the project implementation were two scientific monographs by J. Nazarko (2013a, 2013b). In the first methodical monograph (Nazarko 2013a) the Author introduced and defined the concept of regional business information foresight, developed the research methodology and methods, and the corresponding research instrumentarium. As the important and original scientific achievements described in the work the following should be considered:

- original definition of the phases of research in the foresight cycle (Fig. 1);

- a hybrid approach to combining research methods;

- application of the principles of triangulation: theoretical, methods, researchers and sources;

- taking into account the development trends and unprecedented events in the construction of scenarios;

- verification of scenarios using the Delphi survey;

- preceding the proper Delphi research with the mini-Delphi survey.

The second monograph (Nazarko 2013b) constitutes a case study of the practical application of the developed research methodology of the foresight study on innovation in Mazovia companies. Also in this work a number of original elements developing the theory of foresight studies appear. Inter alia, the operationalization of the main research methodology for the purpose of implementation of a specific foresight project, the way of assessing the likelihood of scenarios, the method of assessing the relevance of scenarios and the method of assessing the significance of factors in Delphi studies may be indicated. The conceptualization and operationalization of the regional business information foresight performed by J. Nazarko significantly expanded the idea of foresight as an innovative tool of strategic management which should focus more on anticipatory thinking and shaping of the conditions that are conductive to development priorities, rather than just implementation of planning activities. The theoretical concept of regional business information foresight developed by the author has been successfully tested in real economic and social environment, which is a measurable effect of interdisciplinarity of the conducted research.

In summary, the following should be considered as the innovative theoretical and methodological contribution to the design and implementation of foresight research, which is also an important contribution to the development of management science:

- introduction and an original definition of the concept of regional business information foresight;

- development of an original approach to the foresight research design based on a theoretical, method, researchers and data triangulation;

- creative development of the concept of SWOT analysis in relation to foresight studies, inter alia, by the introduction of the time dimension to the analysis;

- creative development of the concept of the STEEPVL analysis in relation to foresight studies, inter alia, through its enrichment with the factor analysis; 


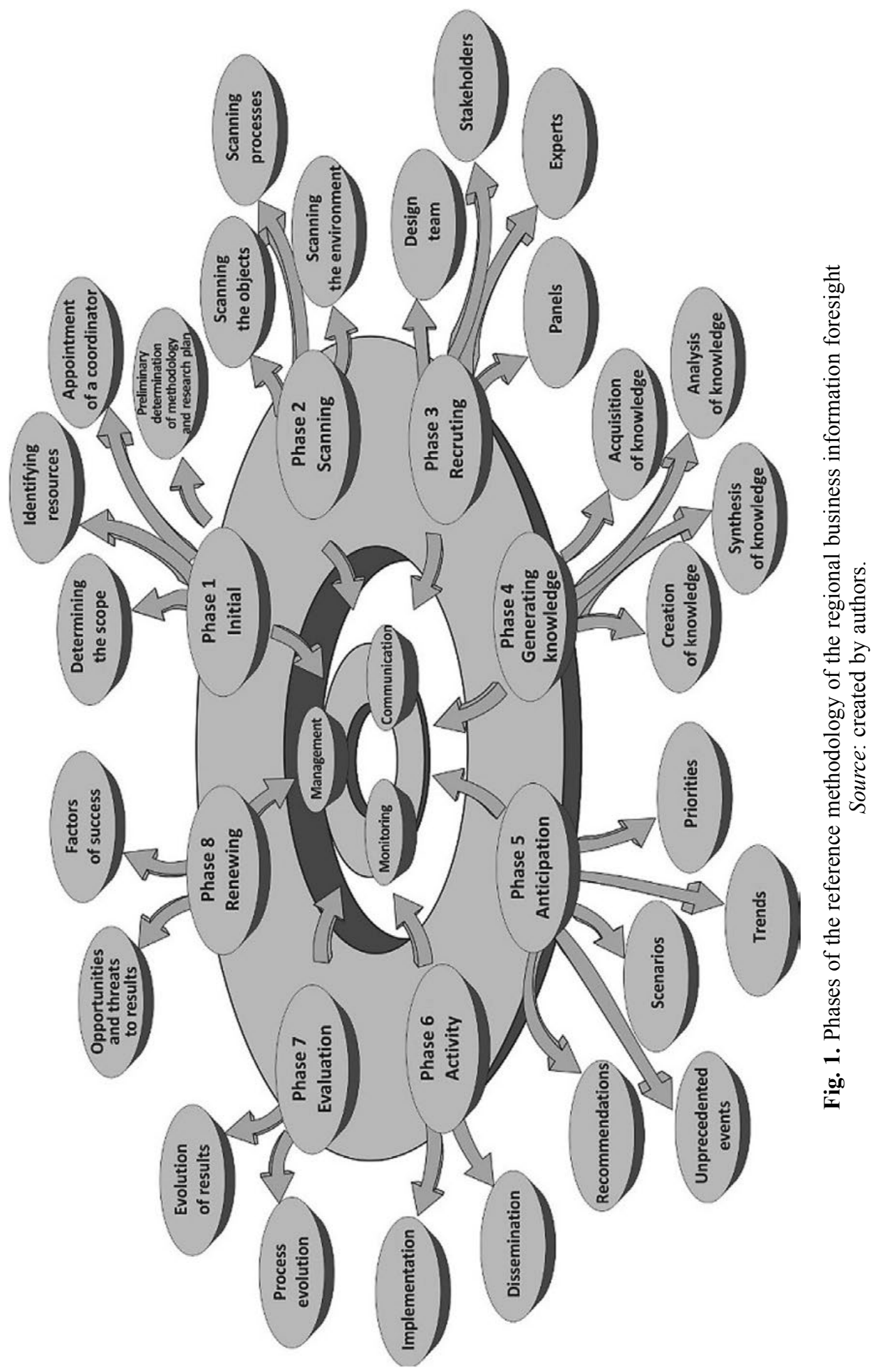


- creative development of the construction methodology of scenarios of development combining the approach of the intuitive logic school, prospective thinking and the Delphi type research;

- development of the original concept of assessment of the relevance of scenarios through the Delphi survey;

- development of the original concept of the foresight project evaluation.

In the development of technology management methodology the following should be considered as the original and creative contribution:

- development of an original approach to the technology mapping;

- development of the methodology for selecting key and priority technologies;

- development of the methodology for selecting the key and priority directions of scientific research.

\section{Conclusions}

Interdisciplinarity in the science practiced by Professor Joanicjusz Nazarko is manifested both in personality traits, such as openness to new ideas, ability to create research teams, a desire of unlimited sharing of knowledge, as well as in the range of the undertaken research topics from the borderline of economic and engineering sciences. In his professional work he is a supporter of an anticipatory management paradigm, determining the trajectory of development (both personal and of his co-workers), which does not imitate others, but heads for where the leaders will be in the future. In the case of Prof. J. Nazarko, both his education and the range of the undertaken research topics reflect, in the full sense of the word, the interdisciplinarity in science, as evidenced by both the scientific novelty of the studied phenomena and their practical applicability.

Prof. J. Nazarko's scientific interdisciplinarity manifests itself in particular in:

- diversity of the undertaken research issues;

- ability to cross the boundaries between the fields of technical and social sciences, identifying problems and seeking solutions at the frontiers of scientific disciplines;

- diversity of the used research approaches (theoretical, methodological, normative, empirical-descriptive);

- flexibility and ability to recognise scientific problems, justified by economic needs;

- ability to work in a diverse environment in terms of competence, age, skills, creating conditions for both personal and individual team members development;

- breaking the stereotypical ways of thinking in the process of solving problems and anticipating future events.

Using the words of Prof. Marian Gorynia (reviewer of the academic achievements in the process of applying for the title of Professor of Economic Sciences), evolution of Prof. J. Nazarko's academic interests followed a unique path that has led to the development of a coherent set of complementary approaches, not dictated by fleeting scientific fashions.

In conclusion, Prof. J. Nazarko in his scientific activity, teaching and organizational activity consistently filled the entire space of the management triangle delineated by $\mathrm{H}$. Mintzberg (McGill University, Canada), whose tips are science, art and crafts. 


\section{References}

Agasisti, T.; Bonomi, F. 2014. Benchmarking universities' efficiency indicators in the presence of internal heterogeneity, Studies in Higher Education 39(7): 1237-1255.

http://dx.doi.org/10.1080/03075079.2013.801423

Bougnol, M.-L.; Dula, J. H. 2006. Validating DEA as a ranking tool: an application of DEA to assess performance in higher education, Annals of Operations Research 145: 339-365. http://dx.doi.org/10.1007/s10479-006-0039-2

Broadwater, R. P.; Sargent, A.; Yarali, A.; Shaalan, H. E.; Nazarko, J. 1997. Estimating substation peaks from load research data, IEEE Transactions on Power Delivery 12(1): 451-456. http://dx.doi.org/10.1109/61.568270

Coelho, G. M.; Galvao, A. C. F.; Guedes, A. C.; Carneiro, I. A.; Chauke, C. N.; Fellows, L. 2012. Strategic foresight applied to the management plan of an innovation development agency, Technology Analysis \& Strategic Management 24(3): 267-283.

http://dx.doi.org/10.1080/09537325.2012.655412

Deidda, M.; Lupianez-Villanueva, F.; Codagnone, C.; Maghiros, I. 2014. Using data envelopment analysis to analyse the efficiency of primary care units, Journal of Medical Systems 38(10): 122-122. http://dx.doi.org/10.1007/s10916-014-0122-1

Docksai, R. 2012. Strategic foresight for corporate and regional development, Futurist 46(1): 49-50.

Doukas, H.; Karakosta, C.; Flamos, A.; Psarras, J. 2014. Foresight for energy policy: techniques and methods employed in Greece, Energy Sources Part B-Economics Planning and Policy 9(2): 109-119.

Ebrahimnejad, A.; Tavana, M.; Lotfi, F. H.; Shahverdi, R.; Yousefpour, M. 2014. A three-stage Data Envelopment Analysis model with application to banking industry, Measurement 49: 308319. http://dx.doi.org/10.1016/j.measurement.2013.11.043

Fancello, G.; Uccheddu, B.; Fadda, P. 2014. Data Envelopment Analysis (DEA) for urban road system performance assessment, Transportation: Can We Do More with Less Resources? - 16th Meeting of the Euro Working Group on Transportation - Porto 2013 111: 780-789.

Figueiredo de Franca, J. M.; de Figueiredo, J. N.; Lapa, J. S. 2010. A DEA methodology to evaluate the impact of information asymmetry on the efficiency of not-for-profit organizations with an application to higher education in Brazil, Annals of Operations Research 173(1): 39-56. http://dx.doi.org/10.1007/s10479-009-0536-1

Gunawan, S.; Shieh, C.-J. 2014. Application of data envelopment analysis to operating performance evaluation of financial system, Anthropologist 17(3): 831-836.

Habegger, B. 2010. Strategic foresight in public policy: reviewing the experiences of the UK, Singapore, and the Netherlands, Futures 42(1): 49-58.

http://dx.doi.org/10.1016/j.futures.2009.08.002

Hansen, H. 2008. The imagination challenge: strategic foresight and innovation in the global economy, Technical Communication 55(4): 423-423.

Jakuszewicz, I.; Kononiuk, A.; Magruk, A.; Nazarko, J. 2006. Inicjatywy foresight w Polsce i na świecie [Foresight initiatives in Poland and around the world], in L. Kiełtyka (Ed.). Multimedia w organizacjach gospodarczych i edukacji. Warszawa: Difin.

Keenan, M.; Miles, I. 2001. A Practical Guide to Regional Foressight. Seville: Institute for Prospective Technological Studies, FOREN Network. http://foresight.jrc.ec.europa.eu/documents/ eur20128en.pdf

Kononiuk, A.; Magruk, A.; Nazarko, J. 2007. The role of Support Group in the Polish National Foresight Programme, in From oracles to dialogue - exploring new ways to explore the future: COST A22. Athens: National Technical University of Athens. 
Kononiuk, A.; Nazarko, J. 2014. Scenariusze w antycypowaniu i kształtowaniu przyszłości [Scenarios in anticipating and shaping the future]. Warszawa: Wolters Kluwer.

Kuźmicz, K. 2013. Korzyści i ograniczenia benchmarkingu w uczelniach [Benefits and constrains of applying benchmarking in higher education institutions], Ekonomia i Zarzadzanie 4: 21-33.

Leitner, K.; Prikoszovits, J.; Schaffhauser-Linzatti, M.; Stowasser, R.; Wagner, K. 2007. The impact of size and specialisation on universities' department performance: a DEA analysis applied to Austrian universities, Higher Education 53: 517-538.

http://dx.doi.org/10.1007/s10734-006-0002-9

Magruk, A. 2012. Hybrydy metod badawczych w studiach przyszłości [Hybrids of research methods in future studies], Ekonomia i Zarzadzanie 2: 37-46.

Morillo, F.; Bordons, M.; Gomez, I. 2003. Interdisciplinarity in science: a tentative typology of disciplines and research areas, Journal of the American Society for Information Science and Technology 54(13): 1237-1249. http://dx.doi.org/10.1002/asi.10326

Nabavi-Pelesaraei, A.; Abdi, R.; Rafiee, S.; Mobtaker, H.G. 2014. Optimization of energy required and greenhouse gas emissions analysis for orange producers using data envelopment analysis approach, Journal of Cleaner Production 65: 311-317.

http://dx.doi.org/10.1016/j.jclepro.2013.08.019

Nazarko, J. 2010. DEA method in efficiency assessment of public higher education institutions, in Proceedings of 8th International Conference on Data Envelopment Analysis Performance Management and Measurement, 10-12 June 2010, Beirut, Lebanon, 177-182.

Nazarko, J. 2011. Kształtowanie polityki proinnowacyjnej regionu np. Foresightu technologicznego NT FOR Podlaskie 2020 [Shaping the pro-innovation policy of the region, e.g., of the Technological Foresight NT FOR Podlaskie 2020], Optimum - Studia Ekonomiczne 2: 241-251.

Nazarko, J. 2013a. Regionalny foresight gospodarczy. Metodologia i instrumentarium badaw$c z e$ [Regional economic foresight. Methodology and research instruments]. Warszawa: ZPWiM http://pbc.biaman.pl/dlibra/docmetadata?id=23865\&from=\&dirids=1\&ver_id=\&lp=1\&QI=

Nazarko, J. 2013b. Regionalny foresight gospodarczy. Scenariusze rozwoju innowacyjności mazowieckich przedsiębiorstw [Regional business information foresight. Scenarios of the innovation development of the enterprises of Mazovia]. Warszawa: ZPWiM http://pbc.biaman.pl/dlibra/doc metadata $\mathrm{id}=23866 \&$ from $=\&$ dirids $=1 \&$ ver $\_\mathrm{id}=\& \mathrm{lp}=1 \& \mathrm{QI}=$

Nazarko, J.; Zalewski, W. 1999. Approach to peak load estimation in power distribution systems, IEEE Transactions on Power Systems 14(3): 809-814. http://dx.doi.org/10.1109/59.780890

Nazarko, J.; Jurczuk, A. 1996. Aspekty ekonomiczne i ekologiczne wdrażania zarządzania zapotrzebowaniem na energię elektryczną [Economic and environmental aspects of the implementation of power demand management], Archiwum Energetyki 3-4: 1-27.

Nazarko, J.; Ustinovičius, L. 2012. Metoda DEA w tworzeniu rankingów szkół wyższych [The DEA method in creating the rankings of acaddemic institutions], in J. Nazarko, J. Ejdys (Eds.). XXVI Konferencja Taksonomiczna: Klasyfikacja i analiza danych - teoria i zastosowania: streszczenia, 2012, Białystok-Lipowy Most. http://pbc.biaman.pl/dlibra/docmetadata?id=21425\&from= \&dirids $=1 \&$ ver_id $=\& 1 \mathrm{p}=1 \& \mathrm{QI}=$

Nazarko, J.; Kononiuk, A. 2013. The critical analysis of scenario construction in the polish foresight initiatives, Technological and Economic Development of Economy 19(3): 510-532. http://dx.doi.org/10.3846/20294913.2013.809030

Nazarko, J.; Broadwater, R. P.; Tawalbeh, N. I.; Ieee. 1998. Identification of statistical properties of diversity and conversion factors from load research data, 18-20 May 1998, Tel-Aviv, Israel, 217-220. http://dx.doi.org/10.1109/MELCON.1998.692375

Nazarko, J.; Kuźmicz, K.; Szubzda, E.; Urban, J. 2007a. Basic benchmarking concepts and conditions for their introduction in the corporate and public sectors, in J. Woźnicki (Ed.). Założenia 
dotyczace rozwoju systemu informacji zarzadczej $w$ szkołach wyższych $w$ Polsce. Warszawa: Oficyna Wydawnicza Politechniki Warszawskiej.

Nazarko, J.; Kuźmicz, K.; Szubzda, E.; Urban, J. 2007b. Koncepcja benchmarkingu i możliwości jej stosowania w szkolnictwie wyższym [The concept of benchmarking and the possibility of its use in higher education], in J.Woźnicki (Ed.). Założenia dotyczace rozwoju systemu informacji zarządczej w szkołach wyższych w Polsce. Warszawa: Oficyna Wydawnicza Politechniki Warszawskiej.

Nazarko, J.; Kuźmicz, K.; Szubzda, E.; Urban, J. 2008a. Analiza oceny parametrycznej z perspektywy benchmarkingu [Analysis of parametric evaluation from the perspective of benchmarking], in J. Woźnicki (Ed.). Benchmarking $w$ systemie szkolnictwa wyższego. Warszawa: Oficyna Wydawnicza Politechniki Warszawskiej.

Nazarko, J.; Kuźmicz, K.; Szubzda, E.; Urban, J. 2008b. Ogólna koncepcja benchmarkingu i jego stosowalność w szkolnictwie wyższym [The general concept of benchmarking and its applicability in higher education], in J. Woźnicki (Ed.). Benchmarking $w$ systemie szkolnictwa wyższego. Warszawa: Oficyna Wydawnicza Politechniki Warszawskiej.

Nazarko, J.; Urban, J.; Komuda, M.; Kuźmicz, K.; Szubzda, E. 2008c. Metoda DEA w badaniu efektywności instytucji sektora publicznego na przykładzie szkół wyższych [The DEA method in the study of the efficiency of public sector on an example of institutions of higher education], Badania Operacyjne i Decyzje 4: 89-105.

Nazarko, J.; Kuźmicz, K.; Urban, J. 2009a. Benchmarking szansą poprawy pozycji konkurencyjnej polskich uczelni [Benchmarking - an opportunity to improve the competitive position of Polish universities], Sprawy Nauki 8-9(148): 31-40.

Nazarko, J.; Kuźmicz, K. A.; Szubzda-Prutis, E.; Urban, J. 2009b. The general concept of benchmarking and its application in higher education in Europe, Higher Education in Europe 34(3-4): 497-510. http://dx.doi.org/10.1080/03797720903356677

Nazarko, J.; Kuźmicz, K. A.; Urban, J. 2009c. Benchmarking szansą na poprawę pozycji konkurencyjnej polskich uczelnim [Benchmarking - an opportunity to improve the competitive position of Polish universities], Nauka i Szkolnictwo Wyższe 2: 60-72.

Nazarko, J.; Dobrzański, G.; Ejdys, J.; Glińska, E.; Kononiuk, A.; Kowalewska, A.; Nazarko, Ł.; Pawluczuk, A.; Olszewska, A.; Urban, W. 2010. Uwarunkowania rozwoju nanotechnologii w województwie podlaskim: wyniki analiz STEEPVL i SWOT [Conditions for the development of nanotechnology in the Podlaskie province: results of STEEPVL and SWOT analyses]. Białystok: Oficyna Wydawnicza Politechniki Białostockiej.

Nazarko, J.; Dębkowska, K.; Ejdys, J.; Glińska, E.; Halicka, K.; Kononiuk, A.; Olszewska, A.; Gudanowska, A.; Magruk, A.; Nazarko, Ł. 2011a. Metodologia i procedury badawcze w projekcie Foresight Technologiczny NT for Podlaskie 2020: regionalna strategia rozwoju nanotechnologii [Methodology and research procedures in the NT Technology Foresight for the Podlaskie 2020 project: regional strategy for the development of nanotechnology]. Białystok: Oficyna Wydawnicza Politechniki Białostockiej.

Nazarko, J.; Wnorowski, H.; Ejdys, J.; Kononiuk, A.; Olszewska, A.; Gudanowska, A. 2011b. Analiza strukturalna czynników rozwoju nanotechnologii w województwie podlaskim [Structural analysis of nanotechnology development factors in the Podlaskie region]. Białystok: Oficyna Wydawnicza Politechniki Białostockiej.

Nazarko, J.; Chodakowska, E.; Jarocka, M. 2012a. Segmentacja szkół wyższych metodą analizy skupień versus konkurencja technologiczna ustalona metodą DEA - studium komparatywne [Segmentation of higher education by cluster analysis versus technological competition is determined by the DEA - a comparative study], Prace Naukowe Uniwersytetu Ekonomicznego we Wrocławiu, ,,Taksonomia” 242: 163-172. 
Nazarko, J.; Ejdys, J.; Kononiuk, J.; Gudanowska, A.; Magruk, A.; Nazarko, Ł. 2012b. Badanie ewaluacyjne projektów foresight realizowanych $w$ Polsce [Evaluation study of foresight projects implemented in Poland]. Warszawa: Ministerstwo Nauki i Szkolnictwa Wyższego.

Nazarko, J.; Brzostowski, N.; Ejdys, J.; Glińska, E.; Halicka, K.; Kononiuk, A.; Kowalewska, A.; Krawczyk-Dembicka, E.; Łojkowski, W.; Magruk, A.; Nazarko, Ł.; Urban, W.; Paszkowski, J.; Pawluczuk, A.; Skorek, A.; Wasiluk, A. 2013a. Podlaska strategia rozwoju nanotechnologii do 2020 roku. Przełomowa wizja regionu [The strategy of nanotechnology development until 2020 of the Podlasie region. The groundbreaking vision of the region]. Białystok: Oficyna Wydawnicza Politechniki Białostockiej.

Nazarko, J.; Ejdys, J.; Glińska, E.; Dębkowska, K.; Kononiuk, A.; Gudanowska, A.; Glińska, U.; Nazarko, Ł. 2013b. Kierunki rozwoju nanotechnologii w województwie podlaskim. Mapy. Marszruty. Trendy [Directions of the development of nanotechnology in the Podlaskie region. Maps. Roadmaps. Trends]. Białystok: Oficyna Wydawnicza Politechniki Białostockiej.

Nazarko, J.; Ejdys, J.; Łojkowski, W.; Olszewska, A.; Gudanowska, A.; Krawczyk-Dembicka, E.; Nazarko, Ł. 2013c. Nanonauka na rzecz rozwoju województwa podlaskiego [Nanoscience for the benefit of development of the Podlaskie province]. Białystok: Oficyna Wydawnicza Politechniki Białostockiej.

Nazarko, J.; Glinska, U.; Kononiuk, A.; Nazarko, L. 2013d. Sectoral foresight in Poland: thematic and methodological analysis, International Journal of Foresight and Innovation Policy 9(1): 19-38. http://dx.doi.org/10.1504/IJFIP.2013.051759

Nazarko, J.; Kurzydłowski, K.; Lewandowska, M.; Łojkowski, W.; Skorek, A.; Ejdys, J.; Dębkowska, K.; Kononiuk, A.; Magruk, A.; Olszewska, A.; Widelska, U.; Gudanowska, A.; Krawczyk, E.; Leończuk, D. 2013e. Kluczowe nanotechnologie w gospodarce województwa podlaskiego [Key nanotechnologies in the economy of the Podlaskie Province]. Białystok: Oficyna Wydawnicza Politechniki Białostockiej.

Nazarko, J.; Saparauskas, J. 2014. Application of DEA method in efficiency evaluation of public higher education institutions, Technological and Economic Development of Economy 20(1): 25-44. http://dx.doi.org/10.3846/20294913.2014.837116

Nazarko, J.; Urban, J. 2007. Sensitivity of DEA models to measurement errors, Annales Universitatis Mariae Curie-Skłodowska, Sectio AI, Informatica 7: 101-106.

Nehme, C. C.; Santos, M. D.; Fellows, L.; Coelho, G. M. 2012. Challenges in communicating the outcomes of a foresight study to advise decision-makers on policy and strategy, Science and Public Policy 39(2): 245-257. http://dx.doi.org/10.1093/scipol/scs015

OECD. 1998. Interdisciplinarity in science and technology. Paris: OECD.

Perek, A. 2014. Wykorzystanie metody DEA do oceny efektywności banków spółdzielczych w Polsce [The use of the DEA method to evaluate the efficiency of cooperative banks in Poland], Economics and Management 3: 222-235.

Sargent, A.; Broadwater, R. P.; Thompson, J. C.; Nazarko, J. 1994. Estimation of diversity and kwhr-to-peak-kw factors from load research data, IEEE Transactions on Power Systems 9(3): 1450-1450. http://dx.doi.org/10.1109/59.336118

Skourdoumbis, A. 2014. International 'benchmarking' studies and the identification of 'education best practice': a focus on classroom teachers and their practices, Australian Educational Researcher 41(4): 411-423.http://dx.doi.org/10.1007/s13384-013-0142-8

Vught, F. V.; Brandenburg, U.; Burquel, N.; Carr, D.; Federkeil, G.; Kuźmicz, K.; Nazarko, J.; Rafael, J.; Sadlak, J.; Urban, J.; Wells, P.; Westerheijden, D. 2008. A practical guide: benchmarking in European higher education. Brussels: European Centre for Strategic Management of Universities. 
Wiley, D. L. 2007. The imagination challenge: strategic foresight and innovation in the global economy, Online 31(4): 53-55.

Winiwarter, V. 2014. An interdisciplinary perspective on 2020 Science. IFF Vienna: OECD.

Yang, J.; Li, X.; Zhou, Z. 2014. A cross-efficiency Data Envelopment Analysis (DEA) based model for measuring environmental performance, Environmental Engineering and Management Journal 13(5): 1139-1146.

Zhou, G.; Chung, W.; Zhang, Y. 2014. Measuring energy efficiency performance of China's transport sector: a data envelopment analysis approach, Expert Systems with Applications 41(2): 709-722. http://dx.doi.org/10.1016/j.eswa.2013.07.095

Joanna EJDYS, is currently an Associate Professor at Faculty of Management, Bialystok University of Technology. She is a Vice Dean for Research and Development and Editor of Economics and Management Journal. Research interest: quality management, foresight studies, strategic management and technology management. Has published more than 30 papers on foresight studies concerning regional and national science and technology innovation policy.

Leonas USTINOVIČIUS. Professor Dr Habil at Vilnius Gediminas Technical University and Bialystok University of Technology. Research interests: Multicriteria evaluation and automated programming of technological decision in construction, Operational research methods, Technology of construction process, Quantitative and qualitative decision making methods, Organization and performance of construction firm.

Jelena STANKEVIČIENĖ. Professor, Dean of the Faculty of Business Management at Vilnius Gediminas Technical University (Lithuania). Her main research topics include assets and liability management, regulation of financial institution, financial management for value creation, value engineering. 